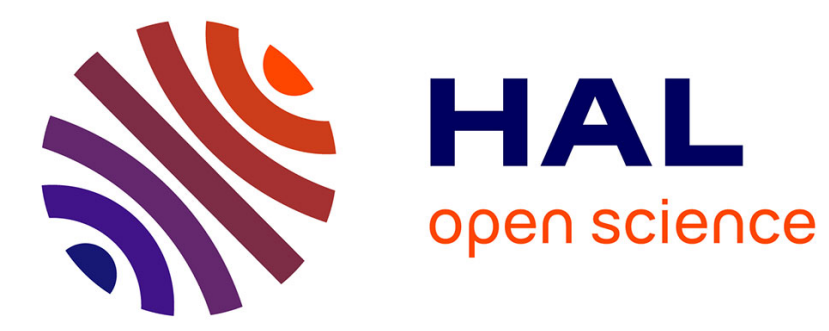

\title{
Sensitivity of spatial indicators for urban terrain characterization
}

Nathalie Long, Erwan Bocher, Thomas Leduc, Guillaume Moreau

\section{To cite this version:}

Nathalie Long, Erwan Bocher, Thomas Leduc, Guillaume Moreau. Sensitivity of spatial indicators for urban terrain characterization. IEEE International Geoscience and Remote Sensing Symposium IGARSS-2008, Jul 2008, Boston, United States. hal-00329504

\section{HAL Id: hal-00329504 https://hal.science/hal-00329504}

Submitted on 11 Oct 2008

HAL is a multi-disciplinary open access archive for the deposit and dissemination of scientific research documents, whether they are published or not. The documents may come from teaching and research institutions in France or abroad, or from public or private research centers.
L'archive ouverte pluridisciplinaire HAL, est destinée au dépôt et à la diffusion de documents scientifiques de niveau recherche, publiés ou non, émanant des établissements d'enseignement et de recherche français ou étrangers, des laboratoires publics ou privés. 


\title{
SENSITIVITY OF SPATIAL INDICATORS FOR URBAN TERRAIN CHARACTERIZATION
}

\author{
Nathalie Long ${ }^{*}$,Erwan Bocher ${ }^{* *}$, Thomas Leduc ${ }^{* *}$, Guillaume Moreau ${ }^{* *}$ \\ *UMR ESO - CESTAN, Université de Nantes, IRSTV, Chemin de la Censive du Tertre, BP 81227, 44312 Nantes Cedex 3, \\ France \\ ${ }^{* *}$ CERMA - UMR AAU, IRSTV, ENSA Nantes, Rue Massenet - BP 81931, 44319 Nantes Cedex 3, France
}

\begin{abstract}
To develop and manage urban territories and to analyze urbanisation impact on environment, an accurate knowledge of the city and its urban fabric is necessary. A physical description like building morphology or land cover/use allows some characterization of the urban terrain. A specific package for a GIS software is developed for urban analysis: UrbSAT (Urban Spatial Analysis Tool). It allows extracting knowledge from various data sources and gives some indicators to real applications (sustainable development, management policy, air quality improvement, etc). It raises issues such as database accuracy and quality, cell shape, size and orientation for the construction of spatial indicators. We present some tests to address those issues.
\end{abstract}

Index Terms - urban fabric characterization, indicators, UrbSAT sensitivity.

\section{INTRODUCTION}

At present more than half of the world population is living in urban areas. Therefore urbanization control has become a major issue. Among the social, economical and ecological factors that are taken into account in decision-making, environmental issues now have a greater impact. To address these issues, researchers are faced with new problems among which are tool disparity, knowledge sharing and enhancement. GIS are become unavoidable tools for the development and management of territories and to analyze urbanization impact on environment. An accurate knowledge of the city and its urban fabric is necessary. A physical description like building morphology or land cover allows some characterization of the urban fabric. A specific package for a GIS software has been developed for urban analysis: UrbSAT. It allows extracting knowledge from various data sources and gives some indicators to real applications (sustainable development, management policy, air quality improvement, urban canopy modeling...). This paper proposes a sensitivity analysis of the spatial indicators produced by UrbSAT. Following the introduction, section 2 relates the framework and the methods used in other studies, section 3 presents the UrbSAT software, the databases and the sensitive tests and then, the results of relevant issues end up the paper with future research.

\section{RELATED WORK}

The UrbSAT development is based on the DFMap methodology, developed within a French laboratory of Ecole Centrale de Nantes [6]. It allows computing not only statistical parameters describing the urban fabric but also aerodynamic parameters like roughness length or displacement height. From the BDTopo database (produced by the French National Geographic Institute, IGN), DFMap converts the initial data into a set of regular squares (vector grid) and computes several functions over each features of the grid. This prototype presents some limitations: among other things, only the BDTopo can be used as data source and GIS facilities (reprojecting a map, rewriting geometric computations or map generation) are not available. To improve this, the OrbisGIS open source GIS software was developed for which urbSAT is a plugin package dedicated to urban analysis.

To characterize the urban fabric, several researchers have developed automated or semi-automated methods to extract urban indicators from database or satellite images. Grimmond \& Souch are the first one to use GIS techniques to compute urban indicators for urban climate analysis [3]. Then, a small community of American scientists has developed the National Urban Database and Access Portal Tool (NUDAPT) which produces gridded outputs of urban parameters capable of driving urban meteorological models [2]. This prototype uses the ESRI ArcGIS software package. With a remote sensing and database approach, Huang et al., propose an analysis of urban form from spatial indicators like compactness, porosity, centrality to compare cities of developing and developed countries [5]. Then, Longley \& Mesev have developed a fine scale data model of population densities to analyze urban sprawl [7].

\section{URBSAT SOFTWARE SENSITIVITY}

In this section, we present the UrbSAT software and the database used to analyze two French cities: Le Havre and Nantes, as well as the tests realized to evaluate the UrbSAT sensitivity and more precisely, the computation methods. 


\subsection{UrbSAT software}

To improve the urban fabric knowledge, the main idea of UrbSAT is to process vector data and to aggregate information on a regular vector grid. It uses a generic processing library called GDMS (Generic Data Source Management System) [1]. It is a semantic abstract layer between the users and the data sources that provides spatial SQL language-based interface. It is thus possible to extend the semantics from typical SQL with customized functions and queries, developed in Java.

\subsection{Urban data sources}

For this study, the French cities of Nantes and Le Havre are the chosen application cases. The BDTopo database and satellite images are available as information sources. The BDTopo database is produced by the French National Institute (IGN) and describes the elements of the urban fabric in details. It includes an inventory of buildings, vegetation areas, roads, and hydrographic network, among other objects. The outlines of these objects are delineated by polylines including some attributes like building height.

The SPOT satellite images of Nantes have a $2.5 \mathrm{~m}$ resolution and were taken in May, 2000. A supervised classification is realized on each district selected on the image to distinguish between built, vegetation and road surfaces (treatments realized with ENVI software RSI).

\subsection{Sensitivity tests}

Several tests are realized and presented here to evaluate the quality and accuracy of urban database, first. Then, on the raster process, the grid cell size and its orientation are tested and evaluated, compared to the source information. All these tests are computed with the UrbSAT software.

\section{RESULTS}

\subsection{Quality and accuracy of urban database}

To evaluate urban database quality to describe the land cover, a very high-resolution satellite image is used on Nantes. Three districts of $1 \mathrm{~km}^{2}$ are selected from both data sources: a city-center with high built density, a collective building district and a residential district (figure 1). From a supervised classification, the density of different types of surface are computed from satellite image and compared to the UrbSAT results from the BDTopo.

Table 1 allows evaluating the under-estimation of land cover from the BDTopo. The difference between these two data sources is low in city center but higher in the districts where the built density is lower. In the BDTopo, all the small surfaces (building surface $<50 \mathrm{~m}^{2}$, vegetation surface
$<80 \mathrm{~m}^{2}$ ) are not present in the database. This lack does not allow describing $100 \%$ of the land cover. The satellite image analysis gives better results but no 3D information is directly available.

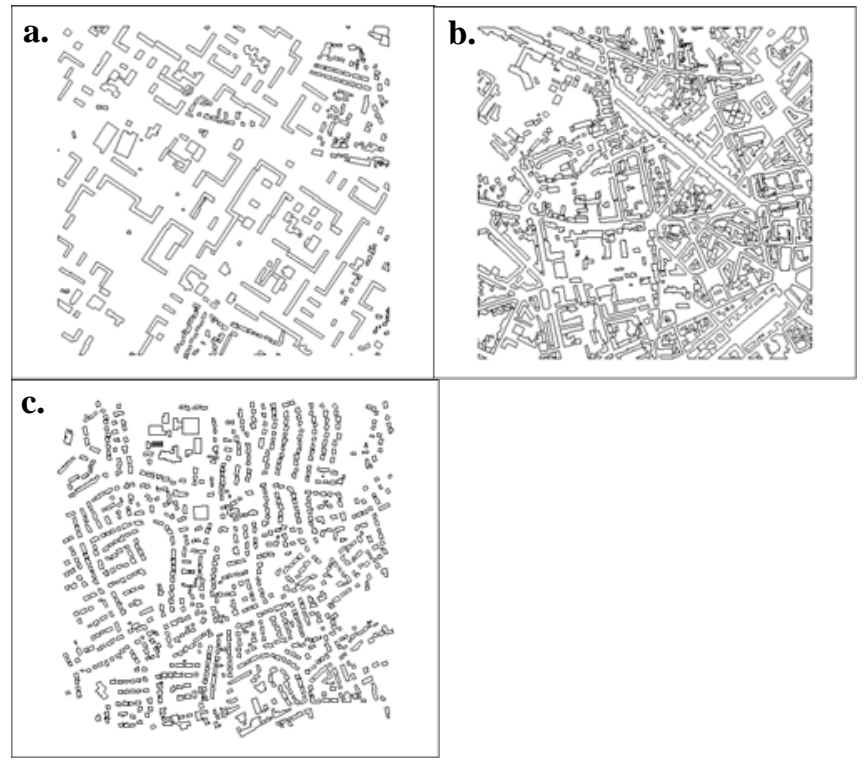

Fig. 1: Test areas of Nantes (a.: collective buildings, b.: city centre, c.: residential district, polygons: buildings)

\begin{tabular}{|l|c|c|c|}
\hline & City center & $\begin{array}{l}\text { Collective } \\
\text { buildings }\end{array}$ & $\begin{array}{l}\text { Residential } \\
\text { buildings }\end{array}$ \\
\hline $\begin{array}{l}\text { SPOT veg. } \\
\text { density }\end{array}$ & 0,23 & 0,25 & 0,13 \\
\hline $\begin{array}{l}\text { BDTopo } \\
\text { veg. density }\end{array}$ & 0,17 & 0,08 & 0,15 \\
\hline $\begin{array}{l}\text { SPOT built } \\
\text { density }\end{array}$ & 0,47 & 0,37 & 0,33 \\
\hline $\begin{array}{l}\text { BDTop built } \\
\text { density }\end{array}$ & 0,38 & 0,18 & 0,18 \\
\hline
\end{tabular}

Table 1: Vegetation and built surfaces densities from BDTopo and SPOT image analysis on three districts

\subsection{Grid cell size tests}

From vector to grid process, as for any sampling, information is modified and the result quality is strongly dependant on the cell size [4]. To evaluate this influence, tests are realized on Le Havre with the mean building height variable. In the BDTopo, each building has an height attribute; an average height is then computed for each cell from the buildings that are totally or partially included in the cell. To improve the quality of this urban indicator, the average building height may be weighted by the surface but 
it's not the case in this test. Four districts are selected in Le Havre: a city centre, a collective building district, a residential district and an industrial area (fig 5). For each district, an average building height per cell $(\mathrm{ABH})$ is computed for $100 \mathrm{~m}, 200 \mathrm{~m}, 300 \mathrm{~m}$ and $500 \mathrm{~m}$ cell sizes. These results are compared to an average of initial building height (IBH), before the raster process, as a reference.

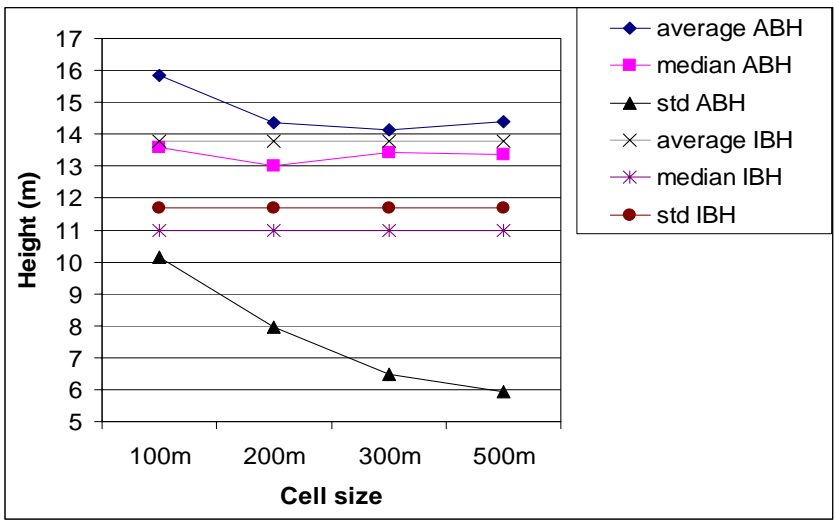

Fig. 2: Statistical variables of the building height indicator for the collective building district

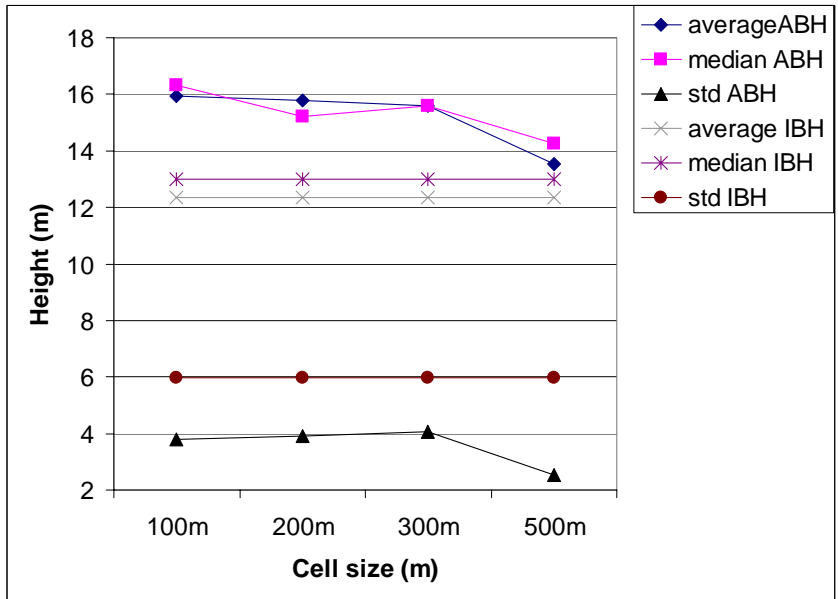

Fig. 3: Statistical variables of the building height indicator for the city center

The vector to grid process has some consequences on data quality: first, the $\mathrm{ABH}$ per cell is higher than the IBH. An over estimate of half a meter to $3.6 \mathrm{~m}$ is shown with respect to district type and resolution. The vector grid process influence is lower for the residential district (fig 4) and higher for the city centre (fig 3). The standard deviation (std) shows a homogenization of the urban fabric by the grid process: the higher the cell size the more erased the differences. We must find the best solution to distinguish between the different districts in the city and describe it. For small structures like the residential buildings, a $200 \mathrm{~m}$ or 300m cell sizes appears to be a satisfactory choice, but for big buildings, a $300 \mathrm{~m}$ or even $500 \mathrm{~m}$ for the city center or the industrial area (fig not shown)) cell size appears necessary to describe these districts (fig 2 and 3).

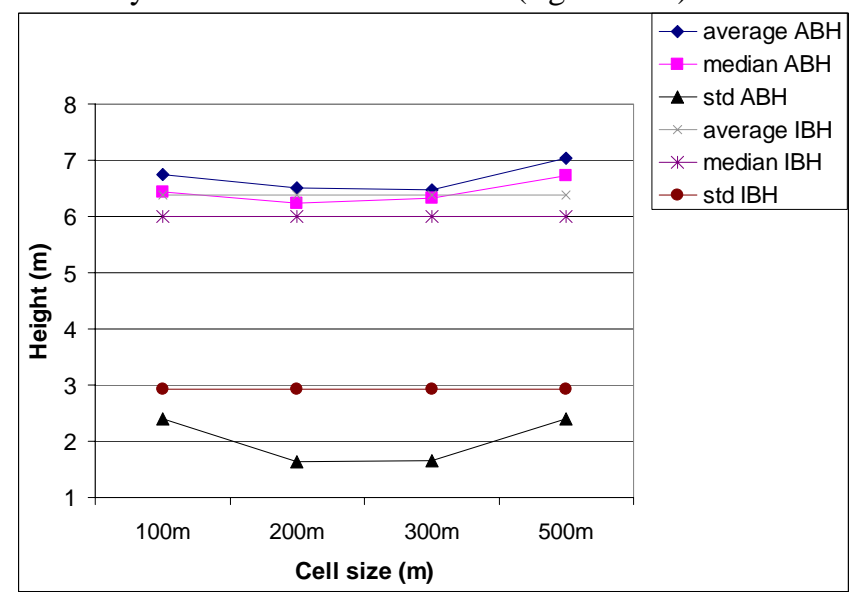

Fig. 4: Statistical variables of the building height indicator for the residential district

\subsection{Grid orientation}

The last tests allow evaluating the influence of grid orientation on urban indicators computations. Main directions appear according to the district, drawn by the street network. The $\mathrm{ABH}$ computations from an oriented grid are compared to computations based on a classical north-south/east-west orientation. The tests are performed on the same districts with a 300m cell size (fig 5).

\begin{tabular}{|l|l|l|l|l|}
\hline & Angle & $\begin{array}{l}\text { ABH } \\
\text { (oriented } \\
\text { grid) }\end{array}$ & $\begin{array}{l}\text { ABH } \\
\text { (NS/EW) }\end{array}$ & IBH \\
\hline Collective & $355^{\circ}$ & $13,63 \mathrm{~m}$ & $14,12 \mathrm{~m}$ & $13,17 \mathrm{~m}$ \\
\hline Industrial & $340^{\circ}$ & $11,38 \mathrm{~m}$ & $11,52 \mathrm{~m}$ & $10,26 \mathrm{~m}$ \\
\hline $\begin{array}{l}\text { Residentia } \\
\text { l }\end{array}$ & $40^{\circ}$ & $6,28 \mathrm{~m}$ & $6,47 \mathrm{~m}$ & $6,38 \mathrm{~m}$ \\
\hline $\begin{array}{l}\text { City } \\
\text { center }\end{array}$ & $355^{\circ}$ & $15,14 \mathrm{~m}$ & $15,58 \mathrm{~m}$ & $12,33 \mathrm{~m}$ \\
\hline
\end{tabular}

Table 2: Average building height per cell and for initial building for four districts with different grid orientation

The results from Table 2 show an improvement of the urban indicator quality when they are computed on an oriented grid, adapted to the main direction of the street network.

\subsection{Circular grid}

The radio-concentric mesh may be interesting for particular applications. For example, for flux simulations over a city, a 
characterization of building morphology and land cover on the main wind direction is essential to define the flux footprint, (this term describes an upwind area "seen" by the instruments measuring vertical turbulent fluxes).

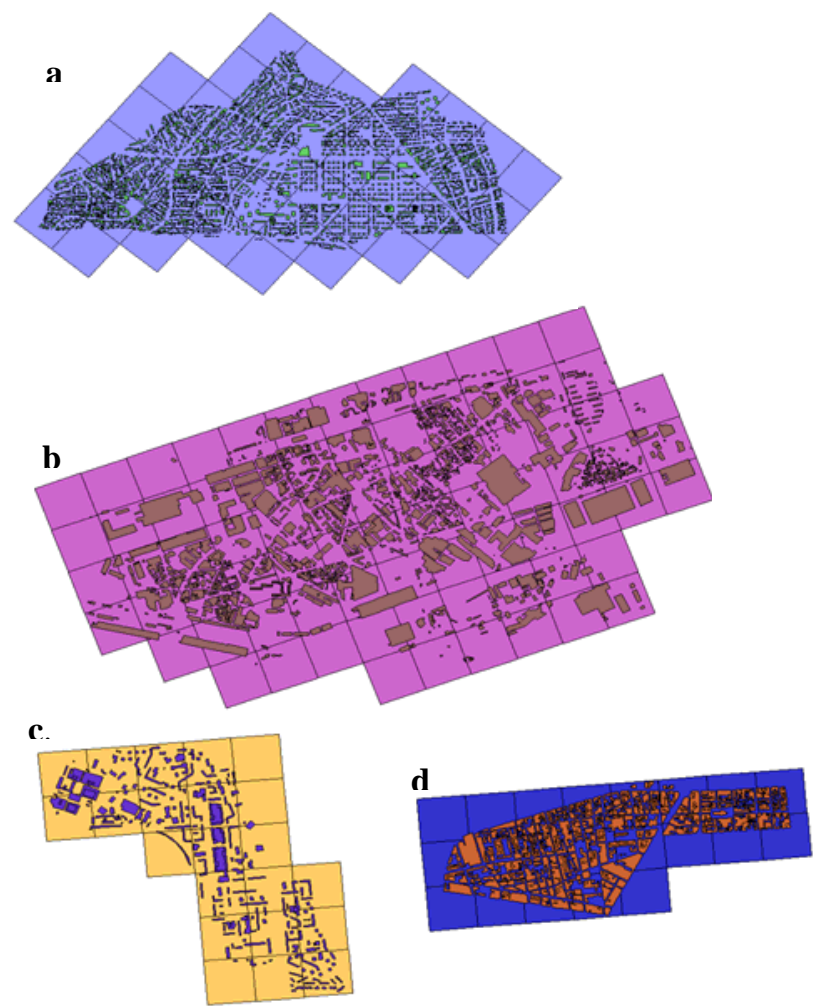

Fig. 5: Oriented grid for four districts (a. residential district, b.: industrial area, c.: collective buildings, d.: city centre, polygons: buildings, Le Havre)

The circular grid allows characterizing this upwind area. The user selects in the grid the cells in a fixed direction, like in figure 6 . For the two directions, the built surface density is respectively 0.10 and 0.14 and the vegetation surface density is 0.40 and 0.30 , in average. The circular grid appears more appropriate than the rectangular grid for the cell selection.

\section{CONCLUSIONS AND PERSPECTIVES}

These different points allow evaluating the UrbSAT sensitivity to define indicators characterizing the urban fabric. The vector to grid process has a strong impact on the data quality. The cell size may be adapted to each urban structure because of the building size variation. In the same way, the grid orientation seems important, and when the grid orientation is the same as the network street, urban indicators are closer to reality.
The vector to grid process is mainly tested here and this study must be supplemented by tests on indicator computation methodology. In other way, the development and the validation of a function defining the main directions of the street network appears essential to complete these first results and automate the process.

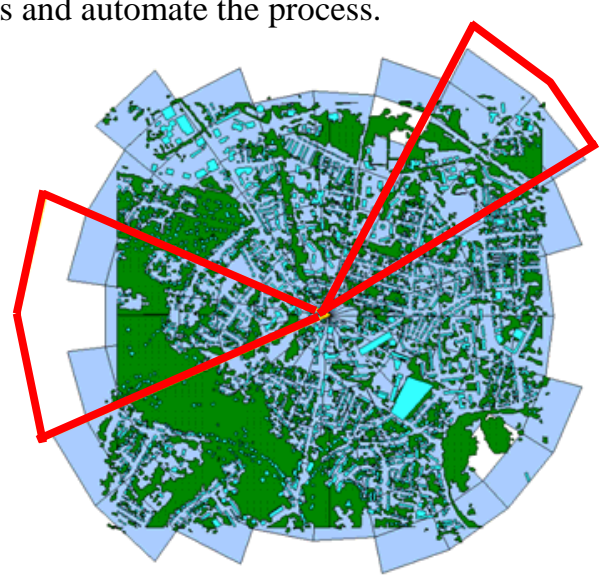

Fig. 6: Circular grid with two flux footprints in Nantes (in dark: vegetation area, in grey: buildings, lines: footprints)

\section{REFERENCES}

[1] E. Bocher, T. Leduc, G. Moreau, F.G. Cortés. GDMS: An abstraction layer to enhance SpatialData Infrastructures usability, Proc. of Agile 2008, Girona, Spain 2008.

[2] Ching J, National urban database and access portal tools (NUDAPT): a project overview, Proc. of the Seventh Symposium on the Urban Environment, San Diego, USA, 2007.

[3] C.S.B. Grimmond, C. Souch. "Surface description for urban climate studies: a GIS based methodology". Geocarto International,9, 47-59.

[4] R. Harris and Z. Chen, Giving dimension to point locations: urban density profiling using population surface models, Computers, environment and urban systems, 29, 115-132, 2005.

[5] J. Huang, X.X. Lu, J.M. Sellers, A global comparative analysis of urban form: applying spatial metrics and remote sensing, Landscape and Urban Planning, 82, 184-197, 2007.

[6] N. Long, P.G. Mestayer, C. Kergomard, Developement of a software to describe the city morphology and to compute aerodynamic parameters from an urban database, Proc. of $4^{\text {th }}$ Symposium on the urban environment, Norfolk, USA, AMS Proceeding, 2002.

[7] P.A. Longley and V. Mesev, On the measurement and generalization of urban form, Environment and Planning A, 32, 473-488, 2000. 